\title{
Canadian Multiculturalism in Historical and Comparative Perspective: Is Canada Unique?
}

\author{
Will Kymlicka
}

\section{INTRODUCTION}

The title of this conference implies that there is something unusual or distinctive about the way Canada deals with issues of cultural diversity. Is this true? In his introductory remarks, Professor Abu-Laban suggested that what is distinctive to Canada is not the sheer fact of diversity - one can find equally high levels of ethnic, linguistic and religious diversity in the United States, Brazil or Nigeria - but rather the legal and institutional response to diversity. ${ }^{1}$ Canada is unique, he suggested, in that our laws and institutions accommodate and promote diversity, most obviously through the Multiculturalism policy.

I think that this is potentially misleading. There have been dramatic changes throughout the western democracies in the way states deal with ethnocultural diversity. The laws and institutions that accommodate and promote diversity in Canada have counterparts in many other countries. Situating the Canadian case within this larger comparative framework helps us understand the deeper forces that have pushed Canada, along with many other countries, in the direction of accommodating diversity.

In this paper, therefore, I will begin by discussing recent trends throughout the western democracies regarding diversity. These trends concern the treatment of immigrant groups, indigenous peoples and substate/minority nationalisms. I will then try to identify what, if anything, is truly distinctive to the "Canadian model." In each of the three areas identified, our progress has been matched, if not overtaken, by other countries. But no other country has confronted the same range of issues as Canada has. Therefore, I will argue that our uniqueness lies not in the way we have

\footnotetext{
B. Abu-Laban, "Conference Agenda," presented at a conference on "Canada: Global Model for a Multicultural State?" (Canadian Multicultural Education Foundation, Edmonton, 26-29 September 2002) [unpublished].
}

responded to these issues, but in the sheer breadth of the challenges we have faced due to the unique composition of Canadian society. In addition, Canadians are distinctive in the way that they have incorporated Canada's policy of accommodating diversity into their sense of national identity. I will conclude with some speculations about the likely future of the Canadian model.

\section{TRENDS REGARDING ETHNOCULTURAL DIVERSITY}

There have been dramatic changes in the way western democracies deal with ethnocultural diversity in the last thirty to forty years. For the purposes of this paper, we can highlight three basic trends. ${ }^{2}$

The first trend concerns the treatment of immigrant groups. In the past, Canada, like other immigrant countries, had an assimilationist approach to immigration. Immigrants were encouraged and expected to assimilate to the pre-existing society. The hope was that, over time, they would become indistinguishable from native-born Canadians in their speech, dress, recreation and general way of life. Any groups that were seen as incapable of this sort of cultural assimilation were prohibited from immigrating to Canada, or from becoming citizens. ${ }^{3}$ However, since the late $1960 \mathrm{~s}$, we have seen a dramatic reversal in this approach. There have been two related changes. First, there was the adoption of race-neutral admissions criteria (the "points system"), so that immigrants to Canada were increasingly from non-European (and

For a more detailed discussion of these three trends see W. Kymlicka, Politics in the Vernacular: Nationalism, Multiculturalism and Citizenship (Oxford: Oxford University Press, 2001) cc. 5-9.

3 For example, Asians were prohibited from entry to Canada for much of the first half of the twentieth century. 
often non-Christian) societies. Second, there was the adoption of a more "multicultural" conception of integration, one which expects that many immigrants will visibly and proudly express their ethnic identity, and which accepts an obligation on the part of public institutions (like the police, schools, media, museums, etc.) to accommodate these ethnic identities.

These two changes have dramatically changed Canadian society. However, it is important to realize that precisely the same two-fold change has occurred in all of the other traditional countries of immigration like Australia, New Zealand, the United States and Britain. All of them have shifted from discriminatory to raceneutral admissions and naturalization policies. And all of them have shifted from an assimilationist to a more multicultural conception of integration. Of course, there are differences in how official or formal this shift to multiculturalism has been. In Canada, as in Australia and New Zealand, this shift was formally and officially marked by the declaration of a multicultural policy by the central government. ${ }^{4}$ But even in the United States, we see similar changes. The United States does not have an official policy of multiculturalism at the federal level, but if we look at lower levels of government, such as states or cities, we find a broad range of multiculturalism policies. For example, if we look at state-level policies regarding the education curriculum, or city-level policies regarding policing or hospitals, we find that they are often indistinguishable from the way provinces and cities in Canada deal with issues of immigrant ethnocultural diversity. As in Canada, they have their own diversity programs and/or equity officers. ${ }^{5}$ As Nathan Glazer, a Harvard sociologist, puts it: "we are all multiculturalists now." Similarly, in Britain, while there is no nation-wide multiculturalism policy, the same basic ideas and principles are pursued through their race relations policy. ${ }^{7}$ All of these countries have accepted the same two-fold change that is at the heart of the Canadian model: adopting a raceneutral admissions and naturalization policy, and

F. Hawkins, Critical Years in Immigration: Canada and Australia Compared (Kingston: McGill-Queen's University Press, 1989); S. Castles, "Multicultural Citizenship: The Australian Experience" in V. Bader, ed., Citizenship and Exclusion (New York: St. Martin's Press, 1997) 113; A. Fleras, "Monoculturalism, Multiculturalism and Biculturalism" (1984) 15 Plural Societies 52.

See infra note 6.

6 N. Glazer, We Are All Multiculturalists Now (Cambridge: Harvard University Press, 1997). Experts on immigration and integration issues have repeatedly demolished the mythical contrast between the American "melting pot" and the Canadian "mosaic," and yet the myth endures in the popular imagination. For the British model of multiculturalism through race relations see A. Favell, Philosophies of Integration: Immigration and the Idea of Citizenship in France and Britain (New York: St. Martin's Press, 2001). imposing on public institutions a duty to accommodate immigrant ethnocultural diversity.

The second trend concerns the treatment of indigenous peoples, such as the Indians, Inuit and Métis in Canada. Other indigenous peoples in the western democracies include the Aboriginal peoples of Australia, the Maori of New Zealand, the Sami of Scandinavia, the Inuit of Greenland and Indian tribes in the United States. In the past, all of these countries had the same goal and expectation that indigenous peoples would eventually disappear as distinct communities by dying out, inter-marriage and assimilation. Various policies were adopted to speed up this process, such as stripping indigenous peoples of their lands, restricting the practice of their traditional culture, language and religion, and undermining their institutions of selfgovernment.

However, there has been a dramatic reversal in these policies; this change, in Canada, started in the early $1970 \mathrm{~s} .{ }^{8}$ Today, the Canadian government accepts, at least in principle, the idea that Aboriginal peoples will exist into the indefinite future as distinct societies within Canada, and that they must have the land claims, treaty rights, cultural rights and self-government rights needed to sustain themselves as distinct societies.

Again, Canada is not unique in this shift. We see the same pattern in all of the other western democracies. Consider the revival of treaty rights through the Treaty of Waitangi in New Zealand, ${ }^{9}$ the recognition of land rights for Aboriginal Australians in the Mabo decision, ${ }^{10}$ the creation of the Sami Parliament in Scandinavia, the evolution of "Home Rule" for the Inuit of Greenland and the laws and court cases upholding self-determination rights for American Indian tribes (not to mention the flood of legal and constitutional changes recognizing indigenous rights in Latin America). ${ }^{11}$ In all of these countries, there is a gradual but real process of decolonization taking place as indigenous peoples regain their lands and self-

8 Key events include the repudiation of the assimilationist 1969 "White Paper on Indian Policy" (Canada, Statement of the Government of Canada on Indian Policy (Ottawa: Queen's Printer, 1969)), the Supreme Court's recognition of Aboriginal title in Calder v. British Columbia (A.G.), [1973] S.C.R. 313, the Mackenzie Valley pipeline inquiry (Canada, Mackenzie Valley Pipeline Inquiry (Toronto: James Lorimer, 1977) (T.R. Berger)), and the James Bay agreement with the Inuit and Cree - the first modern-day treaty in Canada (James Bay and Northern Quebec Agreement, 1975).

Treaty of Waitangi (6 February 1840).

10 Mabo v.Queensland (No.2) (1992), 175 C.L.R. 1 (F.C.).

11 P. Havemann, ed., Indigenous Peoples' Rights in Australia, Canada and New Zealand (Toronto: Oxford University Press, 1999); A. Fleras \& J.L. Elliot, The "Nations Within": Aboriginal-State Relations in Canada, the United States, and New Zealand (Toronto: Oxford University Press, 1992). 
government. This is the second main shift in ethnocultural relations throughout the western democracies.

The third shift concerns the treatment of substate/minority nationalisms, such as the Quebecois in Canada, the Scots and Welsh in Britain, the Catalans and Basques in Spain, the Flemish in Belgium, the French and Italian minorities in Switzerland, the German minority in South Tyrol in Italy, or Puerto Rico in the United States. ${ }^{12}$ In all of these cases, we find a regionally concentrated group that conceives of itself as a nation within a larger state. These groups mobilize behind nationalist political parties to achieve recognition of their nationhood, either in the form of an independent state or through territorial autonomy within the larger state. In the past, all of these countries (except Switzerland) have attempted to suppress these forms of substate nationalism. A regional group with a sense of distinct nationhood was seen as a threat to the state. Various efforts were made to erode this sense of distinct nationhood, including restricting minority language rights, abolishing traditional forms of regional self-government, and encouraging members of the dominant group to settle in the minority group's territory so that the minority becomes a minority even in its traditional territory.

However, there has been a dramatic reversal in this situation as well. Today, all of the countries I have just mentioned have accepted the principle that these substate national identities will endure into the indefinite future, and that their sense of nationhood and nationalist aspirations must be accommodated in some way or other. This accommodation has typically taken the form of what we can call "multination federalism": creating a federal or quasi-federal subunit in which the minority group forms a local majority, and can therefore exercise meaningful forms of selfgovernment. Moreover, the group's language is typically recognized as an official state language, at least within their federal subunit, and perhaps throughout the country as a whole.

At the beginning of the twentieth century, only Switzerland and Canada had adopted this combination of territorial autonomy and official language status for substate national groups. Since then, however, virtually all western democracies that contain sizeable substate nationalist movements have moved in this direction. For example, there was the adoption of autonomy for the Swedish-speaking Aland Islands in Finland after the

12 M. Keating \& J. McGarry, eds., Minority Nationalism and the Changing International Order (Oxford: Oxford University Press, 2001); M. Guibernau, Nations Without States: Political Communities in a Global Age (Cambridge: Polity Press, 1999).
First World War, then there was autonomy for South Tyrol and Puerto Rico after the Second World War, then federal autonomy for Catalonia and the Basque Country in Spain in the 1970s, for Flanders in the 1980 s, and most recently for Scotland and Wales in the 1990 s. ${ }^{13}$ This, therefore, is the third major trend: a shift from suppressing substate nationalisms to accommodating them through regional autonomy and official language rights.

In all three of these areas, Canada's shift to accommodating diversity is simply one manifestation of a much larger trend throughout the west. It is important to emphasize this larger context, for several reasons. First, the fact that most other western democracies have moved in similar directions should, I think, give us some confidence in our policies. It would be puzzling and distressing if no other country had seen the rationality or wisdom of these approaches. Second, it requires us to think more deeply about the underlying causes of these trends. We have a tendency in Canada to personalize our political conflicts, while ignoring the deeper, structural causes at work. For example, some people describe multiculturalism as the product of Pierre Trudeau's distinctive political and philosophical preoccupations, or as the result of the particular electoral strategies and coalitions of the Liberal Party. But these personalistic and parochial explanations cannot explain why multiculturalism was subsequently adopted in Australia or New Zealand, countries with very different types of political leaders and party systems.

Putting the Canadian experience into a broader comparative perspective also allows us to identify the relationship between the three different trends. For example, some commentators, particularly in Quebec, have supposed that multiculturalism was adopted as part of a Machiavellian strategy to attack Quebec nationalism, by encouraging Canadians to think of the Quebecois as just another immigrant group rather than as a distinct nation. There may indeed have been one or two people in Ottawa in 1971 who had this thought. But if this were the only reason for adopting the policy of multiculturalism, then why would Australia or New Zealand adopt it? They do not face any comparable problem of substate nationalism. Instead, they emulated

\footnotetext{
France is the main exception in its refusal to grant autonomy to its main substate nationalist group in Corsica. However, even in France legislation was in fact adopted to accord autonomy to Corsica, and it was only a strange ruling of the Constitutional Court which prevented its implementation. See F. Daftary, "Insular Autonomy: A Framework for Conflict Settlement? A comparative study of Corsica and Aland Islands" ECMI Working Paper 9 (Flensburg: European Centre for Minority Issues, 2000). France too, I think, will soon join the bandwagon.
} 
the Canadian policy because they viewed it as a successful policy for accommodating immigrants. ${ }^{14}$

In any event, the Machiavellian strategy clearly failed. All of the evidence shows that support for multiculturalism in English Canada is positively, not negatively, correlated with support for recognition of Quebecois nationalism (it is also positively correlated with support for Aboriginal rights). In Canada, as in other countries, support for multiculturalism has strengthened, not weakened, support for other forms of accommodation. Examining the experience of other countries can teach us something about the ways in which these three trends can work together.

\section{IS THE CANADIAN MODEL DISTINCTIVE?}

Thus far, I have suggested that the "Canadian model" is much less distinctive than many people suppose. But there are, I think, a few features that are somewhat distinctive about the Canadian experience. The first is simply that we have to deal with all three forms of diversity. Australia and New Zealand, for example, have been grappling with issues of immigration and indigenous peoples, but have no substate nationalist movements. Belgium, Switzerland, Spain and Britain, in contrast, have been grappling with issues of both substate nationalism and immigration, but have no indigenous peoples. Canada is unusual in having to confront all three issues at the same time.

Indeed, I think that this is the only, or primary, sense in which one could describe Canada as a "world leader" in the accommodation of diversity. With respect to any particular form of diversity, there are other countries which probably do a better job than Canada. For example, I think we could learn something from Australia's multiculturalism policy. Australia may have started by emulating Canada's policy, but it has now moved faster and farther than Canada, at least in certain aspects of accommodating immigrant ethnicity. ${ }^{15}$

14 Similarly, the Machiavellian theory does not explain why multiculturalism has remained in force in Canada for the past thirty-one years, and through several different governments, many of whom were committed to accommodating rather than attacking Quebec nationalism. If the motivation for adopting multiculturalism was to attack Quebec nationalism, then Brian Mulroney would presumably have cancelled the policy. Yet, on the contrary, he strengthened it through adoption of the Canadian Multiculturalism Act, R.S.C. 1985 (4th Supp.), c. 24 [Multiculturalism Act]. The Machiavellian theory not only cannot explain why other countries adopted multiculturalism, it cannot explain its persistence in Canada.

15 For example, Australia has done a better job of accommodating immigrant languages than has Canada. See D. Forbes \& J. Uhr, "Multiculturalism and Political Community: Australia and Canada," paper presented at the American Political Science
Similarly, I think we could learn something from New Zealand's treaty regime with the Maori, or the Home Rule provisions for the Inuit in Greenland. Both were initially influenced by developments regarding indigenous peoples in Canada, but have since moved beyond our own, more halting, efforts. And we could learn something from Belgium and Switzerland in terms of the use of federalism and official language rights to accommodate substate nationalism.

However, although other countries may have made better progress in certain areas, none of these countries have made as much progress on as wide of a range of issues as Canada. We are distinctive in the breadth of the challenges we have faced, rather than in the depth with which we have successfully tackled any particular challenge.

Second, Canada is distinctive in the extent to which we have not only legislated, but also constitutionalized, our practices of accommodation. Our commitment to multiculturalism is enshrined not only in statutory legislation, but also in section 27 of the Constitution. ${ }^{16}$ No other western country has constitutionalized multiculturalism. Our commitments to Aboriginal and treaty rights are similarly constitutionalized, in section $35,{ }^{17}$ in a stronger or more explicit fashion than most western countries. Our commitments to federalism and official language rights are also constitutionalized.

This decision to constitutionalize our practices of accommodation is one example of a more general feature of the Canadian experience: the decision to highlight these practices in our national identity and national narratives. While the actual practices of accommodation in Canada may not be that distinctive, we are unusual in the extent to which we have built these practices into our symbols and narratives of nationhood. We tell each other that accommodating diversity is an important part of the Canadian identity; it is a defining feature of the country. This is quite unlike the United States for example. In practice, as I have noted, the United States does accord selfgovernment and treaty rights to American Indians, regional autonomy and language rights to Puerto Rico, and multicultural accommodations to immigrant groups. But these are all quite peripheral to the selfconception of most Americans, and are not considered defining features of the American identity or its

Association Annual Meeting, Boston, 4 September 1998.

16 Canadian Charter of Rights and Freedoms, s. 27, Part I of the Constitution Act, 1982, being Schedule B to the Canada Act 1982 (U.K.), 1982, c. 11.

17 Constitution Act, 1982, s. 35, being Schedule B to the Canada Act 1982, ibid. 
national narrative. Americans accommodate diversity in practice, but they do not shout that fact from the rooftop the way that Canadians sometimes do.

In other words, accommodating diversity has a symbolic importance in Canada that is not matched in most other western countries. This is probably a mixed blessing. I think that the self-conscious affirmation of diversity at the symbolic and constitutional levels has probably helped provide members of various groups in Canada with a stronger sense of security and comfort, and given them the courage and conviction to fight more effectively for changes in their neighbourhoods, schools and public institutions. On the other hand, the preoccupation with symbols has sometimes diverted attention from the actual practices of accommodation. It is sometimes seen as sufficient to adopt a symbolic declaration of the importance of inclusion and diversity, without actually doing the hard work of tackling the barriers and stigmatization that affect various groups.

\section{UNDERLYING SOURCES OF THE TREND TOWARDS ACCOMODATING DIVERSITY}

From a legal and constitutional point of view, the Multiculturalism Act ${ }^{18}$ and the multiculturalism clause of the Constitution Act, $1982^{19}$ provide the foundation for Canada's approach to diversity. But as I have tried to emphasize, the multiculturalism policy did not arise out of thin air. It has its own foundations, rooted in deeper social forces, and the future of the Canadian model depends on the strength of these underlying forces.

In my view, there are four central factors that have made the trend towards accommodating diversity possible, and perhaps even inevitable in the western democracies.

\section{(a) Demographics}

The first factor is simply demographics. In the past, governments had the hope, or the expectation, that minorities would simply disappear by dying out or being assimilated. It is now clear that this is not going to happen. Indigenous peoples, with very high birth rates, are the fastest-growing segment of the Canadian population. In addition, the percentage of immigrants in the Canadian population is growing steadily, and everyone agrees we will need to admit even more immigrants in the future to offset our aging population.

Supra note 14

Supra note 17 at s. 27.
Francophones in Canada are growing both absolutely throughout Canada, and as a percentage within Quebec. One can no longer have the dream or delusion that minorities will disappear. The numbers count, particularly in a democracy, and the numbers are shifting in the direction of non-dominant groups. The same demographic trend applies in most western democracies.

\section{(b) Rights-Consciousness}

The second factor is the human rights revolution, and the resulting development of a "rights consciousness." Since 1948, we have an international order that is premised on the idea of the inherent equality of human beings, both as individuals and as peoples. The international order has decisively repudiated older ideas of a racial or ethnic hierarchy, according to which some peoples were superior to others and thereby had the right to rule over them.

It is important to remember how radical these ideas of human equality are. Assumptions about a hierarchy of peoples were widely accepted throughout the west until the Second World War, when Hitler's fanatical and murderous policies discredited them. Indeed, the whole system of colonialism was premised on the assumption of a hierarchy of peoples, and was the explicit basis of both domestic policies and international law throughout the nineteenth century and first half of the twentieth century.

Today, however, we live in a world where the idea of human equality is unquestioned, at least officially. What matters is not the change in international law per se, which has little impact on most people's everyday lives. The real change has been in people's consciousness. Members of historically subordinated groups today demand equality, and demand it as a right. They believe they are entitled to equality, and entitled to it now, not in some indefinite or millenarian future.

This sort of rights-consciousness has become such a pervasive feature of modernity that we have trouble imagining that it did not always exist. But if we examine the historical records, it is striking how minorities in the past typically justified their claims: not by appeal to human rights or equality, but by appealing to the generosity of rulers in according "privileges," often in return for past loyalty and services. Today, however, groups have a powerful sense of entitlement to equality as a basic human right, not as a favour or charity, and are angrily impatient with what they 
perceive as lingering manifestations of older hierarchies. ${ }^{20}$

\section{(c) Democracy}

The third key factor, I believe, is democracy. Put simply, the consolidation of democracy limits the ability of elites to crush dissenting movements. In many countries around the world, elites ban the political movements of minority groups, pay thugs or paramilitaries to beat up or kill minority leaders, or bribe the police and judges to lock them up. The fear of this sort of repression often keeps minority groups from voicing even the most moderate claims. Keeping quiet is the safest option for minorities in many countries.

In consolidated democracies, however, where democracy is the only game in town, there is no option but to allow minority groups to mobilize politically and advance their claims in public. As a result, members of minority groups are increasingly unafraid to speak out. They may not win the political debate, but they are not afraid of being killed, jailed or fired for trying. It is this loss of fear, combined with rights-consciousness, that explains the remarkably vocal nature of ethnic politics in contemporary western democracies.

Moreover, democracy involves the availability of multiple access points to decision-making. If a group is blocked at one level by an unsympathetic government, then they can pursue their claims at another level. Even if the Canadian Alliance were to win the next federal election, and attempted to cut back on the federal multiculturalism policy, or on indigenous rights, then groups could shift their focus to the provincial or municipal levels. Even if all of these levels are blocked, then they could pursue their claims through the courts, or even through international pressure. This is what democracy is all about: multiple and shifting points of access to power.

Where these three conditions are in place increasing numbers, increasing rights-consciousness, and multiple points of access for safe political

20 Of course, there is no consensus on what "equality" means. Conversely, there is no agreement on what sorts of actions or practices are evidence of "hierarchy." People who agree on the general principle of the equality of peoples may disagree about whether or when this requires accommodating diversity, as opposed to simply identical treatment. In my own view, accommodating diversity is in fact often central to achieving true equality. Treating people as equals is often quite different from treating them identically. While controversial, it seems clear that this conception of equality is increasingly shared by Canadians, and has now been affirmed by the Supreme Court itself. For more on this subject see W. Kymlicka, Multicultural Citizenship: A Liberal Theory of Minority Rights (Oxford: Oxford University Press, 1995) c. 5. mobilization - I believe that the trend towards greater accommodation of diversity is likely to arise. Indeed, I think that it is virtually inevitable. This is the lesson I draw, not only from the Canadian experience, but from the other western democracies as well. These trends have not depended on the presence or absence of particular personalities, particular political parties or particular electoral systems. We see enormous variation across the western democracies in terms of leadership personalities, party platforms and electoral systems. Yet the basic trends regarding diversity are the same, and the explanation, I believe, rests in these three deep sociological facts about numbers, rights-consciousness and opportunity-structures.

\section{(d) Desecuritization}

However, there is one additional factor which may block or reverse the trend towards accommodating diversity. States will not accord greater powers or resources to groups which are perceived as disloyal and, therefore, a threat to the security of the state. In particular, states will not accommodate groups which are seen as likely to collaborate with foreign enemies. In Canada, as in most western democracies, we are very fortunate that this is rarely an issue. For example, if Quebec gains increased powers, or even independence, no one in the rest of Canada worries that Quebec will start collaborating with Iraq, the Taliban or China to overthrow the Canadian state. Quebecois nationalists may want to secede, but an independent Quebec would be an ally of Canada, not an enemy. Quebec would cooperate together with Canada in NATO and other western defence and security arrangements.

This may seem obvious, but it's important to remember that in most parts of the world, minority groups are often seen as a kind of "fifth column," likely to be working for a neighbouring enemy. This is particularly a concern where the minority is related to a neighbouring state by ethnicity or religion, so that the neighbouring state claims the right to intervene to protect "its" minority.

Under these conditions, we are likely to witness what political scientists call the "securitization" of ethnic relations. ${ }^{21}$ Relations between states and minorities are seen, not as a matter of normal democratic politics to be negotiated and debated, but as a matter of state security, in which the state has to limit the normal democratic process in order protect the state. Under conditions of securitization, minority self-

21 For a more extensive discussion of the "securitization" of ethnic relations, see W. Kymlicka \& M. Opalski, eds., Can Liberal Pluralism be Exported? (Oxford: Oxford University Press, $2001)$ at $66-68,366 \mathrm{ff}$. 
organization may be legally limited (e.g. minority political parties banned), minority leaders may be subject to secret police surveillance, the raising of particular sorts of demands may be illegal (e.g. laws against promoting secession) and so on. Even if minority demands can be voiced, they will be flatly rejected by the larger society and the state. After all, how can groups that are disloyal have any legitimate claims against the state? So securitization of ethnic relations erodes both the democratic space to voice minority demands, and the likelihood that those demands will be accepted.

In Canada, however, as in most western countries, ethnic politics have been almost entirely "desecuritized." Ethnic politics in Canada is just that normal, day-to-day politics. Relations between the state and minority groups have been taken out of the "security" box, and put in the "democratic politics" box..$^{22}$ This allows the three factors I discussed earlier to operate freely, and the result is the trend towards accommodation.

\section{THE FUTURE OF THE CANADIAN MODEL}

In my view, these are the four main sociological foundations of the Canadian model: demographics, rights-consciousness, multiple access points and the desecuritization of ethnic relations. As long as these four factors remain strong, I think that the Canadian model will also remain strong, and will endure the vicissitudes of particular leaders, parties and election cycles.

The key question, then, is how stable are these sociological foundations? Is there any likelihood that one or more of these factors might change dramatically? I am not a futurologist, and so have no real basis upon which to make predictions. However, I find it difficult to imagine any dramatic changes in the first three factors, at least not in the near to mid-term future. The demographic trends have deep structural causes that will not change overnight. It is almost

22 It is worth noting that this de-securitization of ethnic politics in Canada even applies to the issue of secession. Even though secessionist political parties wish to break up the state, we assume that they must be treated under the same democratic rules as everyone else, with the same democratic rights to mobilize, advocate and run for office. The same is true of secessionist politics throughout the west, be it in Scotland, Flanders or Catalonia. The reason for this remarkable tolerance of secessionist mobilization, I believe, is precisely the assumption that even if substate national groups do secede, they will become our allies, not our enemies. No one fears that Quebecois, Scottish, Flemish or Catalan nationalists will collaborate with our enemies. inconceivable that the human rights consciousness will disappear in the foreseeable future - if anything, it continues to further consolidate its hold in popular consciousness, domestically and internationally, and becomes further institutionalized in our schools, courts and international organizations. And the democratic system in Canada, with its multiple access points, is robust.

So the only real potential threat that I see concerns the fourth condition: the potential (re)-"securitization" of ethnic relations. This, I think, is the main potential obstacle to the future of multiculturalism and minority rights, whether in Canada or in other western democracies. If ethnic relations become securitized, then all bets are off and the progress we have seen towards accommodating diversity may be reversed.

Personally, I think that this too is quite unlikely. Western countries have the good fortune of living in a very stable geopolitical region. One reason why we do not fear that minorities will collaborate with neighbouring enemies is that we do not have neighbouring enemies. Most western democracies are surrounded by allies, not potential enemies. Most western democracies do not fear being invaded by neighbouring countries, and hence do not even consider the question of how minorities would respond in the event of such an invasion. Our enemies are far away, and few if any of our minorities could plausibly be seen as a fifth-column for these distant enemies.

However, geopolitics are unpredictable, and unexpected events could change the picture quickly. Indeed, we have seen a small glimpse of how this might work after 11 September. Relations between Muslim and Arab immigrants and the Canadian state have, all of a sudden, become "securitized," at least in part. The question of funding Muslim schools, for example, is now seen by some Canadians as a question of state security, rather than of democratic debate and negotiation. Some Canadians worry that such schools could indeed become a fifth-column, training or recruiting extremists or terrorists who would then collaborate with our enemies, and potentially even attack us.

Whether this securitization of relations between the state and Arab/Muslim minorities will endure is likely to depend, I think, on whether there are further dramatic terrorist attacks, and/or whether terrorist cells are uncovered in Canada. If not, then I suspect it will prove to be a passing phase, although it will leave many painful scars for those Arabs and Muslims in Canada who have been labelled as disloyal simply because of their ethnicity or religion. 
In any event, the securitization of relations with Arab/Muslim groups in Canada is, I think, quite contained. As far as I can tell, it has not led to the securitization of ethnic relations more generally. Issues about Quebec's status or about Aboriginal rights, for example, remain firmly inside the "normal democratic politics" box, even after 11 September, as do most issues about levels of immigration or models of multiculturalism. I doubt that Canadian attitudes towards the claims of Guatemalan or Vietnamese immigrants, for example, have substantially changed since 11 September. Particular groups may periodically enter and exit the harsh glare of securitization, depending on changing geopolitical events, but it seems unlikely that these episodes will erode the more general level of public commitment to accommodating diversity.

If this analysis is correct, then the future for the Canadian model is fairly bright, as indeed it is for the practices of accommodating diversity in other western democracies. The sociological foundations of multiculturalism and minority rights in Canada look pretty strong to me. This optimistic conclusion runs counter to that of many commentators, who say we are witnessing a retreat from multiculturalism. It would take another paper to discuss why other people have reached such opposite conclusions. But I would like to conclude by offering one small suggestion in this regard. It seems undeniable that the word multiculturalism has lost some of its lustre, and is less likely to cross the lips of politicians and public intellectuals. I think that this is the inevitable fate of any word that begins as a rallying cry for progressive dissident social movements but which is then adopted by state bureaucracies. To use the word "multiculturalism" today, unlike in the 1960s, is to speak the language of bureaucrats, and hence is deeply unfashionable amongst both the right and the left. However, I believe that the ideas that were once conveyed by that word - in particular, the idea that assimilationist policies are illegitimate, and that public institutions must fairly accommodate diversity remain as powerful and as persuasive today as ever before, if not more so. People have simply found other terms to convey these ideas, and to work through their implications, including terms like "integration," "inclusion," "equity," “citizenship," "tolerance," "nondiscrimination," "participation," “opportunity," "diversity" and so on.

We should measure the success of multiculturalism, not by how often people use the word, but by the extent to which all of our words are now interpreted in light of multiculturalist ideals. We may not use the word "multiculturalism" as often, or with the same enthusiasm, and we may prefer to talk about "integration" or "citizenship" instead. But our conceptions of what integration and citizenship mean have themselves been radically altered over the past 30 years by multiculturalist ideals. All of these alternate terms have a different meaning today than they had 30 years ago. We have a different idea about what integration, inclusion and participation mean, and about what the barriers to them are.

In a sense, I think that "multiculturalism" is a victim of its own success. Multiculturalism has so strongly changed the way we think about society and politics that we no longer need the term the way we did thirty years ago. In the past, we needed to talk explicitly about multiculturalism, as a way of pushing us to rethink earlier ideas about citizenship, community and nationhood in the light of the realities of diversity. We needed the term and the symbol of multiculturalism to remind us that older models of assimilation and exclusion were unacceptable and unworkable. But today we do not need the reminder. We all know that those older models are dead. We have not yet worked out what to replace them with, but virtually all of the terms and concepts we use to think about those alternatives are premised on the twin pillars of multiculturalism: the rejection of assimilationist policies and the acceptance of a duty to accommodate. The word multiculturalism may be unfashionable, but those twin assumptions are more widely accepted than ever before, and indeed are often simply taken for granted. In that sense, as Glazer says, "we are all multiculturalists now, "23 however much or little we like the word.

\section{Will Kymlicka}

Professor, Department of Philosophy, Queen's University

This paper was presented at the conference on "Canada: Globel Model for a Multicultural State?" organized by the Canadian Multicultural Education Foundation (Edmonton, 25-28 September 2002). 